\title{
The Effect of Spent Mushroom Substrate and Cow Slurry on Sugar Content and Digestibility of Alfalfa Grass Mixtures
}

\author{
E. Malinowska $(1)$ and K. Jankowski \\ Siedlce University of Natural Sciences and Humanities, Faculty of Agrobioengineering and Animal Husbandry, Prusa 14 Street, \\ 08-110 Siedlce, Poland
}

Correspondence should be addressed to E. Malinowska; elzbieta.malinowska@uph.edu.pl

Received 13 December 2019; Accepted 25 February 2020; Published 17 March 2020

Academic Editor: Allen Barker

Copyright (C) 2020 E. Malinowska and K. Jankowski. This is an open access article distributed under the Creative Commons Attribution License, which permits unrestricted use, distribution, and reproduction in any medium, provided the original work is properly cited.

\begin{abstract}
The aim of this paper is to evaluate the effect of different doses of spent mushroom substrate and cow slurry on sugar content and digestibility of hybrid alfalfa and grass mixtures. The main factors were different doses of organic material: mushroom substrate and slurry, and the following legume grass mixtures: M1-orchard grass (Dactylis glomerata), perennial ryegrass (Lolium perenne), and hybrid alfalfa (Medicago x varia T. Martyn); M2-orchard grass, hybrid alfalfa; M3-perennial ryegrass, hybrid alfalfa. In each growing season, the mixtures were harvested three times during three years of their full use. Sugar content and dry matter digestibility were determined with near-infrared spectroscopy (NIRS) using the NIRFlex N-500 spectrometer. Of all fertilizer treatments, the application of mushroom substrate at a dose of $20 \mathrm{t} \cdot \mathrm{ha}^{-1}$ in combination with $40 \mathrm{~m}^{3}$ of slurry resulted in the best forage quality with its highest digestibility. In the mixture of perennial ryegrass and hybrid alfalfa increasing doses of mushroom substrate with decreasing doses of slurry lowered soluble sugar content and digestibility.
\end{abstract}

\section{Introduction}

Legume grass mixtures provide one of the best balanced types of roughage [1-4]. Such mixtures are often used in organic production systems [5], being beneficial for successive plants in crop rotation [6].

A starting dose of mineral nitrogen used in the cultivation of these plants can be replaced with organic fertilizer or organic waste, such as slurry or mushroom substrate $[7,8]$. The use of organic materials is necessary when organic matter content in the soil is low. About $45 \%$ of European soils have a low or very low content of organic carbon (0-2\%). In Poland, $90 \%$ of agricultural soils in the layer of $0-25 \mathrm{~cm}$ contain $0-2 \%$ of organic carbon, i.e., below $3.5 \%$ of humus [9]. Research on agricultural use of mushroom substrate in east central Poland is extremely important because this region is undergoing intense development of mushroom production, significant not only in Poland but in the whole of Europe. Application of organic materials in the cultivation of feed crops, that is, legume grass mixtures, not only can improve plant yields, but it also increases soil fertility.

Cantalapiedra-Hijar et al. [10] and Olszewska et al. [11] found that legume plants and their mixtures exhibited higher digestibility than grass grown on its own. Dry matter digestibility largely depends on the time of harvesting and decreases with plant aging [12], and it increases in consecutive harvests [13-15]. Many authors [16-18] reported that between 18 and $70 \%$ of nitrogen in grass grown with legumes comes from its fixing from the atmosphere by the latter plants. This way growing grass with legumes reduces costs and reduces the losses of nitrogen leached deeper into the soil [19].

The aim of the paper is to evaluate the content of sugars and digestibility of hybrid alfalfa and grass mixtures treated with different doses of spend mushroom substrate and cow slurry. 


\section{Materials and Methods}

This paper is based on a three-year field experiment carried out between 2013 and 2015 and replicated three times. It was set up in the autumn of 2012 in a split-plot design, with plots of $3.0 \mathrm{~m}^{2}$. The main experimental factors were different doses of mushroom substrate and cow slurry applied to legume grass mixtures. There were three experimental factors in the study: (1) treatment, with spent mushroom substrate and cow slurry used separately and in various combinations; (2) harvests/years; (3) legume grass mixtures.

There were the following units in the experiment:

(1) control unit (no fertilization) (0);

(2) spent mushroom substrate $\left(30 \mathrm{t} \cdot \mathrm{ha}^{-1}\right)$ (SMS);

(3) cow slurry $\left(60 \mathrm{~m}^{3} \cdot \mathrm{ha}^{-1}\right)(\mathrm{CS})$;

(4) mushroom substrate $\left(10 \mathrm{t} \cdot \mathrm{ha}^{-1}\right)+$ cow slurry $\left(60 \mathrm{~m}^{3} \cdot \mathrm{ha}^{-1}\right)\left(\mathrm{SMS}_{10}+\mathrm{CS}_{60}\right)$

(5) mushroom substrate $\left(20 \mathrm{t} \cdot \mathrm{ha}^{-1}\right)+$ cow slurry $\left(40 \mathrm{~m}^{3} \cdot \mathrm{ha}^{-1}\right)\left(\mathrm{SMS}_{20}+\mathrm{CS}_{40}\right)$

(6) mushroom substrate $\left(30 \mathrm{t} \cdot \mathrm{ha}^{-1}\right)+$ cow slurry $\left(20 \mathrm{~m}^{3} \cdot \mathrm{ha}^{-1}\right)\left(\mathrm{SMS}_{30}+\mathrm{CS}_{20}\right)$.

The slurry was collected from cows producing 6,000 to 8,000 liters of milk a year and housed indoors on straw bedding, with manure removed daily. Before seeds were planted, the mushroom was mixed with a $20-25 \mathrm{~cm}$ layer of the soil. The slurry was applied before each growing cycle with control plots treated with the same amount of water. On plots with lower amounts of slurry additional quantities of water were used so that the amount of liquids was the same on each unit.

Three plant species were involved in the experiment: alfalfa hybrid of Tula variety, the Bora variety of orchard grass, and perennial ryegrass of Info variety. These species were grown as three legume grass mixtures, with an equal share of each component: M1-orchard grass, perennial ryegrass, alfalfa hybrid; M2-orchard grass, hybrid alfalfa; M3-perennial ryegrass, alfalfa hybrid. Taking into account different germination capacity the sowing rate of plants grown on their own was as follows $\left(\mathrm{kg} \cdot \mathrm{ha}^{-1}\right)$ : hybrid alfalfa Medicago x varia Martyn-23; Dactylis glomerata-21; Lolium perenne-31. During each growing season all the mixtures were harvested three times, with the first harvest at the end of May, the second at the beginning of July, and the third in mid September. The first date of harvesting mixtures was carried out at the stage of heading for grass, the second at the stage of beginning of flowering of alfalfa, and the third at full budding of alfalfa.

The experiment was founded on the soil of the anthropogenic order, culture Earth type, and the subtype of hortisol (Polish classification system), with the granulometric composition of loamy sand. Before the experiment started, the carbon content in soil organic compounds (Corg) was $13.50 \mathrm{~g} \cdot \mathrm{kg}^{-1} \mathrm{DM}$, with total nitrogen content of $1.30 \mathrm{~g} \cdot \mathrm{kg}^{-1}$ $\mathrm{DM}$, while $\mathrm{C}: \mathrm{N}$ ratio was $10.4: 1$, and $\mathrm{pH}$ was 6.8 . The content of total nitrogen, phosphorus $(\mathrm{P})$, and potassium $(\mathrm{K})$ in the mushroom substrate was as follows: $24.50 ; 9.50 ; 13.20 \mathrm{~g} \cdot \mathrm{kg}^{-1}$ $\mathrm{DM}$, and in cow slurry it was $48.00 ; 12.64 ; 43.16 \mathrm{~g} \cdot \mathrm{kg}^{-1} \mathrm{DM}$.
The total nitrogen content was determined by the Kjeldahl method, and the concentration of other chemical elements was measured by the ICP-AES method, after dry mineralization in a muffle furnace at $450^{\circ} \mathrm{C}$. The organic carbon content in the soil was determined by the oxidation-titration method. In order to determine the temporal variation of meteorological elements and their effects on vegetation, Sielianinov's hydrothermal coefficient was calculated [20] on the basis of monthly sums of precipitation $(\mathrm{P})$ and monthly sums of air temperature $\left(\sum t\right)$, using the formula: $K=(P / 0.1) \sum t$.

Optimum temperature and precipitation (Table 1) were only in April 2014 and in September 2015. In the remaining months of the growing periods, weather conditions varied from extremely dry in August 2015 to extremely wet in May 2013. The best conditions were at the beginning of each growing period. It can be concluded that the most difficult conditions for plant development were in 2015, when, apart from May and the end of the growing period, the weather varied from moderately dry to extremely dry.

Within three years of their full use, plants were harvested three times in each growing season. Each time soluble sugar content and dry matter digestibility were determined with near-infrared spectroscopy (NIRS), using the NIRFlex N-500 spectrometer.

The results of the research were processed statistically using three factor analysis of variance. Fisher's F-test was used to determine whether the impact of experimental factors was significant, while the value of the $\mathrm{LSD}_{0.05}$ was calculated with Tukey's test. The Statistica program, version 10.0 StatSoft, was applied for all other calculations [21].

\section{Results}

Sugar content in the mixtures varied depending on the treatment, growing season, and harvest (Tables 2 and 3). In regard to treatment, plants from plots where slurry was applied had the highest content of sugars (Table 2) of $64.81 \mathrm{~g} \cdot \mathrm{kg}^{-1}$, while it was the lowest $\left(54.68 \mathrm{~g} \cdot \mathrm{kg}^{-1}\right)$ in the forage from the control. Generally, mushroom substrate, slurry, and their mixture resulted in a statistically significant increase in sugar content in relation to the control.

Additionally, sugar content steadily increased in a statistically significant way throughout the experiment from $51.76 \mathrm{~g} \cdot \mathrm{kg}^{-1}$ in the first year to $67.19 \mathrm{~g} \cdot \mathrm{kg}^{-1}$ in the third one (Table 2). The plans responded to almost all fertilizer treatments with an increase in sugar content. The highest content was in the forage harvested in 2015, the last year of the experiment, on the plot where slurry was applied $\left(77.19 \mathrm{~g} \cdot \mathrm{kg}^{-1}\right)$, with the lowest in 2013 in plants treated with $20 \mathrm{t}$ of the mushroom substrate with $40 \mathrm{~m}^{3}$ of slurry $\left(48.31 \mathrm{~g} \cdot \mathrm{kg}^{-1}\right)$.

Regarding the differences between mixtures, their sugar content (Table 3) was very similar. Statistically significant differences were only noted between the first mixture (orchard grass, perennial ryegrass, and hybrid alfalfa) and the third (perennial ryegrass and hybrid alfalfa). They contained, respectively, 59.36 and $58.36 \mathrm{~g} \cdot \mathrm{kg}^{-1}$ of sugar. However, both mushroom substrate and slurry increased the average content of soluble sugars in all mixtures. The highest content 
TABLE 1: Sielianinov's hydrothermal coefficient $(K)$ in the growing season.

\begin{tabular}{|c|c|c|c|c|c|c|c|}
\hline \multirow{2}{*}{ Year } & \multicolumn{7}{|c|}{ Month } \\
\hline & April & May & June & July & August & September & October \\
\hline 2013 & $2.56(\mathrm{sw})$ & 3.07 (ew) & $2.11(\mathrm{w})$ & $0.84(\mathrm{~d})$ & 0.78 (d) & $2.53(\mathrm{sw})$ & $0.60(\mathrm{sd})$ \\
\hline 2014 & $1.36(\mathrm{o})$ & $1.87(\mathrm{mw})$ & $1.64(\mathrm{mw})$ & $0.59(\mathrm{sd})$ & $1.92(\mathrm{mw})$ & $0.64(\mathrm{sd})$ & $0.12(\mathrm{ed})$ \\
\hline 2015 & $1.22(\mathrm{md})$ & $2.63(\mathrm{sw})$ & $0.87(\mathrm{~d})$ & $1.08(\mathrm{md})$ & $0.18(\mathrm{ed})$ & $1.46(\mathrm{o})$ & $1.94(\mathrm{dw})$ \\
\hline
\end{tabular}

$K \leq 0.4$ extreme drought (ed), $0.4<K \leq 0.7$ severe drought (sd), $0.7<K \leq 1.0$ drought (d), $1.0<K \leq 1.3$ moderate drought (md), $1.3<K \leq 1.6$ optimal (o), $1.6<K \leq 2.0$ moderately wet (mw), $2.0<K \leq 2.5$ wet (w), $2.5<K \leq 3.0$ severely wet (sw), $K>3.0$ extremely wet (ew).

TABLe 2: The effect of fertilizer on sugar content $\left(\mathrm{g} \cdot \mathrm{kg}^{-1} \mathrm{DM}\right)$ in legume grass mixtures in consecutive growing seasons.

\begin{tabular}{|c|c|c|c|c|c|c|c|c|}
\hline \multirow{2}{*}{ Mixture $(C)$} & \multirow{2}{*}{ Year $(B)$} & \multicolumn{6}{|c|}{ Treatment $(A)$} & \multirow{2}{*}{ Mean } \\
\hline & & 0 & SMS & CS & $\mathrm{SMS}_{10}+\mathrm{CS}_{60}$ & $\mathrm{SMS}_{20}+\mathrm{CS}_{40}$ & $\mathrm{SMS}_{30}+\mathrm{CS}_{20}$ & \\
\hline \multirow{3}{*}{ Orchard grass + ryegrass + alfalfa } & 2013 & 48.67 & 52.24 & 78.13 & 60.50 & 50.32 & 46.82 & 56.11 \\
\hline & 2014 & 48.78 & 49.01 & 59.31 & 57.59 & 62.47 & 55.50 & 55.44 \\
\hline & 2015 & 59.34 & 61.20 & 80.93 & 63.75 & 68.30 & 65.62 & 66.52 \\
\hline \multirow{4}{*}{ Orchard grass + alfalfa } & 2013 & 49.11 & 53.83 & 50.98 & 51.43 & 46.13 & 51.88 & 50.56 \\
\hline & 2014 & 56.78 & 62.22 & 50.71 & 62.78 & 51.03 & 68.90 & 58.74 \\
\hline & 2015 & 66.25 & 70.21 & 68.67 & 71.52 & 63.47 & 66.02 & 67.69 \\
\hline & 2013 & 47.67 & 50.36 & 52.09 & 51.06 & 48.49 & 41.94 & 48.60 \\
\hline \multirow[t]{2}{*}{ Ryegrass + alfalfa } & 2014 & 55.33 & 56.67 & 60.49 & 60.71 & 62.24 & 59.21 & 59.11 \\
\hline & 2015 & 60.24 & 62.69 & 81.97 & 66.65 & 66.13 & 66.47 & 67.36 \\
\hline \multicolumn{9}{|l|}{ Fertilizer effect } \\
\hline \multirow{2}{*}{\multicolumn{9}{|c|}{ Growing season effect }} \\
\hline & & & & & & & & \\
\hline 2013 & & 48.48 & 52.14 & 60.40 & 54.33 & 48.31 & 46.88 & 51.76 \\
\hline 2014 & & 53.63 & 55.97 & 56.84 & 60.36 & 58.58 & 61.20 & 57.76 \\
\hline 2015 & & 61.94 & 64.70 & 77.19 & 67.31 & 65.97 & 66.04 & 67.19 \\
\hline
\end{tabular}

LSD $_{0.05}$ for: $A=1.54 ; B=0.890 ; C=0.890 ; B / C=1.54 ; C / B=1.54 ; C / A=1.54 ; A / B=2.66 ; A / C=1.88 ; B / A=2.18$, SMS: spent mushroom substrate, $C S:$ cow slurry.

TABLE 3: The effect of fertilizer on sugar content $\left(\mathrm{g} \mathrm{kg}^{-1} \mathrm{DM}\right)$ in legume grass mixtures in consecutive harvests.

\begin{tabular}{|c|c|c|c|c|c|c|c|c|}
\hline \multirow{2}{*}{ Mixture $(C)$} & \multirow{2}{*}{ Harvest (cuts) $(B)$} & \multicolumn{6}{|c|}{ Treatment $(A)$} & \multirow{2}{*}{ Mean } \\
\hline & & 0 & SMS & $\mathrm{CS}$ & $\mathrm{SMS}_{10}+\mathrm{CS}_{60}$ & $\mathrm{SMS}_{20}+\mathrm{CS}_{40}$ & $\mathrm{SMS}_{30}+\mathrm{CS}_{20}$ & \\
\hline \multirow{3}{*}{ Orchard grass + ryegrass + alfalfa } & I & 53.11 & 55.85 & 66.37 & 51.49 & 56.37 & 54.37 & 56.26 \\
\hline & II & 50.94 & 51.21 & 77.54 & 59.80 & 68.63 & 57.79 & 60.99 \\
\hline & III & 52.73 & 55.40 & 74.46 & 70.55 & 56.09 & 55.78 & 60.83 \\
\hline \multirow{3}{*}{ Orchard grass + alfalfa } & I & 53.44 & 59.34 & 52.28 & 55.79 & 56.96 & 58.68 & 56.08 \\
\hline & II & 57.11 & 61.00 & 62.83 & 65.06 & 49.25 & 60.40 & 59.28 \\
\hline & III & 61.58 & 65.93 & 55.25 & 64.88 & 54.43 & 67.71 & 61.63 \\
\hline \multirow{3}{*}{ Ryegrass + alfalfa } & I & 49.44 & 53.12 & 66.79 & 58.32 & 53.99 & 51.37 & 55.51 \\
\hline & II & 58.84 & 61.00 & 60.63 & 59.02 & 62.51 & 56.06 & 59.68 \\
\hline & III & 54.95 & 55.58 & 67.13 & 61.08 & 60.36 & 60.20 & 59.88 \\
\hline \multicolumn{9}{|l|}{ Mixture effect } \\
\hline Orchard grass + ryegrass + alfalfa & & 52.26 & 54.15 & 72.79 & 60.61 & 60.36 & 55.98 & 59.36 \\
\hline Orchard grass + alfalfa & & 57.38 & 62.09 & 56.78 & 61.91 & 54.55 & 62.26 & 59.00 \\
\hline Ryegrass + alfalfa & & 54.41 & 56.57 & 64.85 & 59.47 & 58.95 & 55.88 & 58.36 \\
\hline \multicolumn{9}{|l|}{ Harvest effect } \\
\hline I & & 52.00 & 56.10 & 61.81 & 55.20 & 55.77 & 54.81 & 55.95 \\
\hline II & & 55.63 & 57.74 & 67.00 & 61.29 & 60.13 & 58.08 & 59.98 \\
\hline III & & 56.42 & 58.97 & 65.61 & 65.50 & 56.96 & 61.23 & 60.78 \\
\hline
\end{tabular}

LSD $_{0.05}$ for: $A=1.38 ; B=0.802 ; C=0.802 ; B / C=1.39 ; C / B=1.39 ; C / A=1.39 ; A / B=2.40 ; A / C=1.70 ; B / A=1.96$, SMS: spent mushroom substrate, CS: cow slurry.

$\left(72.79 \mathrm{~g} \cdot \mathrm{kg}^{-1}\right)$ was in orchard grass with ryegrass and alfalfa grown on the plot with slurry, and lowest $\left(54.41 \mathrm{~g} \cdot \mathrm{kg}^{-1}\right)$ in ryegrass with alfalfa on the control.

There were differences in sugar content between consecutive harvests. As an average effect of both organic fertilizers it gradually increased from the first harvest $\left(55.95 \mathrm{~g} \cdot \mathrm{kg}^{-1}\right)$ to the third one $\left(60.78 \mathrm{~g} \cdot \mathrm{kg}^{-1}\right)$.

It was found that dry matter digestibility was variable depending on the fertilizer, growing season, and harvest (Tables 4 and 5). Both mushroom substrate and slurry 
TABle 4: The effect of fertilizer on the digestibility of legume grass mixtures (\%) in consecutive growing seasons.

\begin{tabular}{|c|c|c|c|c|c|c|c|c|}
\hline \multirow{2}{*}{ Mixture $(C)$} & \multirow{2}{*}{ Year $(B)$} & \multicolumn{6}{|c|}{ Treatment $(A)$} & \multirow{2}{*}{ Mean } \\
\hline & & 0 & SMS & $\mathrm{CS}$ & $\mathrm{SMS}_{10}+\mathrm{CS}_{60}$ & $\mathrm{SMS}_{20}+\mathrm{CS}_{40}$ & $\mathrm{SMS}_{30}+\mathrm{CS}_{20}$ & \\
\hline \multirow{3}{*}{ Orchard grass + ryegrass + alfalfa } & 2013 & 48.44 & 49.42 & 53.11 & 57.65 & 54.59 & 46.15 & 51.56 \\
\hline & 2014 & 52.00 & 56.74 & 58.91 & 55.35 & 60.50 & 56.64 & 56.69 \\
\hline & 2015 & 50.42 & 47.16 & 53.97 & 49.70 & 53.42 & 49.66 & 50.72 \\
\hline \multirow{4}{*}{ Orchard grass + alfalfa } & 2013 & 54.67 & 57.34 & 54.58 & 49.29 & 55.44 & 50.41 & 53.62 \\
\hline & 2014 & 58.22 & 60.80 & 55.20 & 52.71 & 58.20 & 57.50 & 57.11 \\
\hline & 2015 & 51.36 & 51.02 & 50.68 & 50.75 & 47.94 & 46.69 & 49.74 \\
\hline & 2013 & 42.44 & 43.80 & 53.87 & 58.14 & 55.20 & 48.39 & 50.31 \\
\hline \multirow[t]{2}{*}{ Ryegrass + alfalfa } & 2014 & 51.00 & 53.70 & 59.76 & 57.40 & 60.32 & 58.82 & 56.83 \\
\hline & 2015 & 49.61 & 51.57 & 52.30 & 53.43 & 50.51 & 45.45 & 50.48 \\
\hline \multicolumn{9}{|l|}{ Fertilizer effect } \\
\hline & & 50.91 & 52.39 & 54.71 & 53.82 & 55.13 & 51.08 & 53.01 \\
\hline \multicolumn{9}{|l|}{ Growing season effect } \\
\hline 2013 & & 48.52 & 50.18 & 53.85 & 55.03 & 55.08 & 48.32 & 51.83 \\
\hline 2014 & & 53.74 & 57.08 & 57.96 & 55.15 & 59.68 & 57.65 & 56.88 \\
\hline 2015 & & 50.46 & 49.92 & 52.32 & 51.29 & 50.62 & 47.27 & 50.31 \\
\hline
\end{tabular}

$\mathrm{LSD}_{0.05}$ for: $A=1.12 ; B=0.648 ; C=0.648 ; B / C=1.12 ; C / B=1.12 ; C / A=1.12 ; A / B=1.938 ; A / C=1.37 ; B / A=1.59$, SMS: spent mushroom substrate, $C S:$ cow slurry.

TABle 5: The effect of fertilizer on digestibility of legume grass mixtures (\%) in consecutive harvests.

\begin{tabular}{|c|c|c|c|c|c|c|c|c|}
\hline \multirow{2}{*}{ Mixture $(C)$} & \multirow{2}{*}{ Harvest (cuts) $(B)$} & \multicolumn{6}{|c|}{ Treatment $(A)$} & \multirow{2}{*}{ Mean } \\
\hline & & 0 & SMS & CS & $\mathrm{SMS}_{10}+\mathrm{CS}_{60}$ & $\mathrm{SMS}_{20}+\mathrm{CS}_{40}$ & $\mathrm{SMS}_{30}+\mathrm{CS}_{20}$ & \\
\hline \multirow{3}{*}{ Orchard grass + ryegrass + alfalfa } & $\mathrm{I}$ & 52.00 & 51.24 & 55.42 & 50.50 & 55.39 & 47.67 & 52.04 \\
\hline & II & 49.37 & 48.43 & 56.77 & 58.44 & 59.05 & 53.97 & 54.34 \\
\hline & III & 49.49 & 53.64 & 53.80 & 53.75 & 54.07 & 50.81 & 52.59 \\
\hline \multirow{3}{*}{ Orchard grass + alfalfa } & $\mathrm{I}$ & 54.22 & 55.17 & 50.46 & 45.54 & 53.34 & 44.32 & 50.51 \\
\hline & II & 54.67 & 54.53 & 55.58 & 55.69 & 53.60 & 51.45 & 54.25 \\
\hline & III & 55.36 & 59.46 & 54.41 & 51.51 & 54.64 & 58.83 & 55.70 \\
\hline \multirow{3}{*}{ Ryegrass + alfalfa } & $\mathrm{I}$ & 46.56 & 47.85 & 55.88 & 59.35 & 53.15 & 49.10 & 51.98 \\
\hline & II & 53.59 & 55.50 & 53.38 & 52.16 & 59.26 & 51.15 & 54.17 \\
\hline & III & 42.91 & 45.73 & 56.68 & 57.46 & 53.62 & 52.41 & 51.47 \\
\hline \multicolumn{9}{|l|}{ Mixture effect } \\
\hline Orchard grass + ryegrass + alfalfa & & 50.29 & 51.10 & 55.33 & 54.23 & 56.17 & 50.82 & 52.99 \\
\hline Orchard grass + alfalfa & & 54.75 & 56.39 & 53.48 & 50.92 & 53.86 & 51.53 & 53.49 \\
\hline Ryegrass + alfalfa & & 47.68 & 49.69 & 55.31 & 56.32 & 55.34 & 50.89 & 52.54 \\
\hline \multicolumn{9}{|l|}{ Harvest effect } \\
\hline I & & 50.93 & 51.42 & 53.92 & 51.80 & 53.96 & 47.03 & 51.51 \\
\hline II & & 52.54 & 52.82 & 55.24 & 55.43 & 57.31 & 52.19 & 54.25 \\
\hline III & & 49.26 & 52.94 & 54.96 & 54.24 & 54.11 & 54.02 & 53.25 \\
\hline
\end{tabular}

LSD $_{0.05}$ for: $A=3.02 ; B=1.75 ; C=$ n.s.; $B / C=3.03 ; C / B=3.03 ; C / A=3.03 ; A / B=5.23 ; A / C=3.70 ; B / A=4.29$, n.s.: not significant; SMS: spent mushroom substrate, CS: cow slurry.

application affected dry matter digestibility in a statistically significant way. The highest $(55.13 \%)$ was in plants from the plot treated with $20 \mathrm{t}$ of the mushroom substrate and $40 \mathrm{~m}^{3}$ of slurry, while the lowest $(50.91 \%)$ was on the control.

As regards differences between growing seasons (Table 4), average digestibility was the highest (56.88\%) in plants harvested in 2014, the second year, while the lowest $(50.31 \%)$ was noted in the third year. Analyzing fertilizer effect in different growing seasons (Table 4), it was found that the highest digestibility (59.68\%) was exhibited by the forage in the second year on the plot with $20 \mathrm{t}$ of the mushroom substrate and $40 \mathrm{~m}^{3}$ of slurry. Plants from the plot on which 30 tons of mushroom substrate and $20 \mathrm{~m}^{3}$ of slurry were applied in the third year had the lowest digestibility $(47.27 \%)$. In relation to the control slurry application, each year resulted in an increase in plant digestibility.

The highest digestibility over the three growing seasons (Table 5) was $53.49 \%$ for the mixture of orchard grass with alfalfa, with the lowest for ryegrass with alfalfa $(52.54 \%)$. The differences between dry matter digestibility of different mixtures were not statistically significant. Regarding the effect of organic fertilizer (Table 5), orchard grass with hybrid alfalfa had the highest digestibility of all mixtures (56.39\%) on the plot with the mushroom substrate, and the lowest $(47.68 \%)$ was the mixture of perennial ryegrass with hybrid alfalfa on the control. The mixture of orchard grass with alfalfa had better digestibility when it was treated with mushroom substrate than with slurry, while for the mixture 
of ryegrass and alfalfa it was the opposite, with plants having higher digestibility on the plot with slurry.

Digestibility varied between individual harvests (Table 5) with the highest $(54.25 \%)$ in the forage from the second cut. In the first harvest it was the lowest (51.51\%) differing significantly from the forage of the second and third harvests.

\section{Discussion}

The mixtures of alfalfa with grass have higher and more stable yields and better nutritional value as fodder than the same plants grown in monoculture [22]. In the present experiment, organic fertilizer raised soluble sugar content. Similar results were observed by Wróbel et al. [23], who demonstrated a slight increase in sugar content in their experiment. Czyż et al. [24] found that this content varied between different mixtures and the differences were statistically significant. According to the latter authors, sugar content is affected by plant development stage at which they are harvested.

According to Dembek and Łyszczarz [25] ryegrass and orchard grass grown on their own contained about $100 \mathrm{~g} \cdot \mathrm{kg}^{-1}$ of sugar. Godlewska and Ciepiela [26] found that the same plant species contained, on average, $73.7 \mathrm{~g} \cdot \mathrm{kg}^{-1}$ of soluble sugars, while in the case of Festulolium braunii it was much higher, amounting to $130.9 \mathrm{~g} \cdot \mathrm{kg}^{-1}$. In general, Fabaceae plants have lower amounts of soluble sugars than grass [27]. However, legumes contain essential nutrients for livestock, being rich in protein, vitamins, and minerals. Compared with grass species they have high content of crude protein, low content of carbohydrates, and high buffer capacity, which is why legumes are difficult to conserve as silage $[28,29]$.

Sugar content in plants from different harvests is affected, among other factors, by air temperature in individual months. With rising air temperature, plant respiration increases, requiring higher amounts of sugar [30].

Digestibility is a measure of how much forage is absorbed from the gastrointestinal tract into the body. According to Stachowicz [31], roughage intended for feeding ruminants should have digestibility at around $65 \%$. The forage in the present experiment had somewhat lower digestibility.

The present results with dry matter digestibility of alfalfa mixtures with grasses, being the highest in the second year and lowest in the third, were confirmed by Gawel [14]. Slightly higher digestibility than in the present experiment (about $60.3 \%$ ) was exhibited by the mixture of alfalfa with Festulolium braunii in an experiment conducted by Sosnowski [2]. The same author [2] and Borowiecki [32] demonstrated that to a large extent, forage digestibility is affected by the share of alfalfa in a mixture. Sosnowski [2] reported that out of three legume grass mixtures harvested three times a year, red clover with Festulolium braunii had much higher digestibility than alfalfa with Festulolium braunii.

The present experiment showed a significant effect of fertilizer treatment on dry matter digestibility, which again was confirmed by Sosnowski [2]. Small differences in digestibility between different mixtures containing grasses, alfalfa, or other Fabaceae plants were reported by Gawel [33]. However, it was generally higher than in the present experiment. It can be concluded that other Fabaceae plants, like Onobrychis viciifolia or Lotus corniculatus L., added to alfalfa and grass mixtures increase forage digestibility.

Plant digestibility is also affected by the length of a growing cycle, that is, the number of harvests in the growing period, which is closely related to the development stage at which crops are harvested, but also by the pace of plant senescence $[12,13]$. In his experiment Gaweł [14] found that dry matter digestibility of legume grass mixtures harvested five times was as high as $80 \%$.

\section{Conclusions}

Both soluble carbohydrate content and dry matter digestibility indicate that the response of individual legume grass mixtures to fertilizer treatments was very diverse.

Of all fertilizer combinations, forage with the highest digestibility was obtained as an effect of the application of $20 \mathrm{t}^{\mathrm{h}} \mathrm{ha}^{-1}$ of the spent mushroom substrate with $40 \mathrm{~m}^{3}$ of cow slurry.

In the mixture of ryegrass and alfalfa increasing doses of the mushroom substrate and decreasing doses of cow slurry lowered soluble sugars content and digestibility.

The slurry in comparison with mushroom substrate increased the content of soluble sugars in legume grass mixtures, as well as their digestibility.

\section{Data Availability}

The results of sugar content and stability of grass mixtures used to support the findings of this study are included within the article.

\section{Conflicts of Interest}

The authors declare no conflicts of interest.

\section{Acknowledgments}

This research was supported under the research theme no. 40/20/B by the Ministry of Science and Higher Education.

\section{References}

[1] W. Nowak, J. Sowiński, A. Liszka-Podkowa, and A. Jama, "Nutritional value of one-year legume-grass mixtures," Grassland Science in Poland, vol. 11, pp. 139-146, 2008.

[2] J. Sosnowski, "The feed value of Festulolium braunii mixtures with red clover and alfalfa supplied with soil's fertilizer," Grassland Science in Poland, vol. 14, pp. 127-135, 2011.

[3] K. Jankowski, E. Malinowska, J. Sosnowski, B. WiśniewskaKadżajan, and A. Kaczorek, "Effects of spent mushroom substrate and slurry on nutritional value of grass and Medicago x varia T. Martyn mixtures," International Journal of Agricultural and Biological Engineering, vol. 11, no. 3, pp. 61-66, 2018. 
[4] K. Jankowski and E. Malinowska, "Fiber fraction content in legume-grass mixtures treated with mushroom substrate and cow slurry," Agronomy Journal, vol. 111, no. 4, pp. 1650-1657, 2019.

[5] I. Duer, "Plon suchej masy kilku odmian koniczyny uprawianej w ekologicznym i integrowanym systemie produkcji oraz akumulacja azotu w glebie," Zeszyty Naukowe Akademii Rolniczej w Krakowie Sesja Naukowa, vol. 62, pp. 69-77, 1999.

[6] J. Kryszak, "Wartość gospodarcza mieszanek motylkowatotrawiastych w uprawie polowej," Roczniki Adademii Rolniczej w Poznaniu, Rozprawa Naukowa, vol. 338, p. 108, 2003.

[7] D. Kalembasa and B. Wiśniewska, "The influence of fertilisation with bed after mushroom production on the amount of iron, manganese and boron in Lolium multiflorum," Acta Agrophysica, vol. 168, no. 3, pp. 725-732, 2009.

[8] B. Wiśniewska-Kadżajan and K. Jankowski, "Effect of mushroom substrate supplemented with minerals on yield of biomass and protein of orchard grass," Acta Agrophysica, vol. 22, no. 3, pp. 335-344, 2015.

[9] S. S. Gonet, "Ochrona zasobów materii organicznej gleb," in Rola Materii Organicznej w Środowisku, S. S. Gonet and M. Markiewicz, Eds., pp. 7-29, PTSH, Wrocław, Poland, 2007.

[10] G. Cantalapiedra-Hijar, D. R. Yáñez-Ruiz, A. I. MartínGarcía, and E. Molina-Alcaide, "Effects of forage: concentrate ratio and forage type on apparent digestibility, ruminal fermentation, and microbial growth in goats," Journal of Animal Science, vol. 87, no. 2, pp. 622-631, 2009.

[11] M. Olszewska, S. Grzegorczyk, and A. Kobyliński, “The yield and relative feed value of mixtures of Dactylis glomerata L. with medicago media pers. depending on the varying participation of alfalfa in sowing," Acta Agrophysica, vol. 24, no. 3, pp. 485-496, 2017.

[12] E. Gaweł and J. Żurek, "Nutritional value of selected lucerne cultivars," Biuletyn IHAR, vol. 225, pp. 167-174, 2003.

[13] J. Żurek and J. Chrust, "Influence of legume-grass mixture utilization system on its productivity and nutritive value," Advances Agricultural Sciences Problem Issues, vol. 479, pp. 313-320, 2001.

[14] E. Gawel, "Nutritive value of legume-grass mixtures cultivated in organic farms," Journal of Research and Applications Agricultural Engineering, vol. 57, no. 3, pp. 91-97, 2012.

[15] E. Gaweł and M. Nędzi, "Effect of frequency at which herbage left ungrazed by cows is cut on the feed value of the legumegrass sward under organic management," Journal of Research and Applications Agricultural Engineering, vol. 59, no. 3, pp. 50-55, 2014.

[16] A. P. Mallarino, W. F. Wedin, R. S. Goyenola, C. H. Perdomo, and C. P. West, "Legume species and proportion effects on symbiotic dinitrogen fixation in legume-grass mixtures," Agronomy Journal, vol. 82, no. 4, pp. 785-789, 1990.

[17] G. H. Heichel and K. I. Henjum, "Dinitrogen fixation, nitrogen transfer, and productivity of forage legume-grass communities," Crop Science, vol. 31, no. 1, pp. 202-208, 1991.

[18] D. E. Farnham, "Harvest management and cultivars effects on dinitrogen fixation and nitrogen transfer in forage legume grass mixtures," Dissertation-Abstracts-International-D-Sciences-and-Engineering, vol. 53, pp. 1116B-1117B, 1992.

[19] D. Nyfeler, O. Huguenin-Elie, M. Suter, E. Frossard, and A. Lüscher, "Grass-legume mixtures can yield more nitrogen than legume pure stands due to mutual stimulation of nitrogen uptake from symbiotic and non-symbiotic sources," Agriculture, Ecosystems \& Environment, vol. 140, no. 1-2, pp. 155-163, 2011.
[20] B. Skowera and J. Puła, "Pluviometric extreme conditions in spring season in Poland in the years 1971-2000," Acta Agrophysica, vol. 3, no. 1, pp. 171-177, 2004.

[21] StatSoft, Inc., STATISTICA 2011 (Data Analysis Software System), StatSoft, Tulsa, OK, USA, 2011, http://www.statsoft. $\mathrm{com} /$.

[22] A. Radkowski, I. Radkowska, and E. Sosin-Bzducha, "Effect of different proportions of alfalfa mixed with meadow fescue on the nutritional value of the silage used in the fattening of young Simmental cattle," Roczniki Naukowe Zootechniki, vol. 43, no. 2, pp. 215-227, 2013.

[23] B. Wróbel, K. J. Zielińska, and A. U. Fabiszewska, "Evaluation of bacterial inoculation effectiveness in ensilage of meadow sward fertilized with natural fertilizers," Journal of Research and Applications Agricultural Engineering, vol. 58, no. 4, pp. 233-237, 2013.

[24] H. Czyż, H. Jänicke, T. Kitczak, and M. Bury, "The usefulness of grass mixtures with Festulolium braunii and Lolium perenne for the renewal of grasslands on mucky organic soil," Water-Environment-Rural Areas, vol. 15, pp. 17-29, 2015.

[25] R. Dembek and R. Łyszczarz, "Plantago lanceolata sward participation and its effect on pasture sward yields and quality," Grassland Science in Poland, vol. 15, pp. 41-52, 2012.

[26] A. Godlewska and G. A. Ciepiela, "The effect of natural growth regulators obtained from Eklonia maxima and mineral nitrogen on true protein and simple sugar contents of Dactylis glomerata L. and Festulolium braunii (K. richt.) A. camus," Turkisch Journal of Field Crops, vol. 18, no. 2, pp. 247-253, 2013.

[27] H. Ścibor and E. Gaweł, "Yields and nutritional value of multispecific mixtures of clover with grasses," Pułwski Diary, vol. 137, pp. 149-161, 2004.

[28] Y. X. Yang, Cz. Wang, H. X. Lian, C. M. Zhang, and X. F. Hu, "Effect of alfalfa meal on production performance, egg quality and egg yolk color layers," Journal Huazhong Agricultural, vol. 23, pp. 314-319, 2004.

[29] X. L. Li and L. Q. Wan, "Research progress on Medicago sativa silage technology," Acta Pratacultural Science, vol. 14, pp. 9-15, 2005.

[30] K. A. Watts, "Carbohydrates in forage: what is a safe grass?" in Proceedings of the 2008 Kentucky Equine Research Conference "Facing Today's Nutritional challenges. Advanced Kentucky Equine Research", pp. 1-13, Versailles, KY, USA, 2008.

[31] T. Stachowicz, Racjonalne Wykorzystanie Użytków Zielonych W Gospodarstwie Ekologicznym, Centrum Doradztwa Rolniczego w Brwinowie, Radom, Poland, 2010.

[32] J. Borowiecki, "Przydatność festulolium do uprawy w mieszankach z lucerną mieszańcową," Puławski Diary, vol. 109, pp. 35-44, 1997.

[33] E. Gaweł, "The effect of the way and frequency of utilization of lucerne-grass mixtures on their yield, botanical composition and quality," Water-Environment-Rural Areas, vol. 24, pp. 5-18, 2008. 